\title{
Strategi Komunikasi Radio Citra FM Kendal dalam Meningkatkan Minat Pendengar
}

\author{
Sarinah1, Miftahul Huda², Viro Dharma Saputra ${ }^{3}$ \\ 123Ilmu Komunikasi, Fakultas Ilmu Sosial dan Ilmu Politik, Universitas Selamat Sri Kendal Jawa Tengah \\ Indonesia \\ 凶sarinahazzahra015@gmail.com,mashudadm@gmail.com,viiro.dharma@gmail.com
}

\begin{abstract}
Radio is a communication medium that emerged in the telecommunications era. Radio as a medium of communication provides convenience for the public to obtain information. Along with the development of high information technology, radio has various challenges to maintain its existence. This study aims to determine the communication strategy used by Radio Citra in increasing listener interest.

In this study, using the post-positivist paradigm, and including the type of qualitative research. This study uses three data collection techniques, namely observation, interviews, and documentation. The data analysis technique in this study used the stages of data reduction, data presentation, and drawing conclusions.

The results of this study are that Citra radio's strategy in increasing listener interest is by packaging interesting programs, using social media Facebook, Instagram and streaming for broadcasts, functioning broadcasters as the spearhead and heart, actively engaging the community directly, and using conformity strategies. Radio Citra also makes careful program planning, makes program productions, executes programs to broadcast programs according to a predetermined plan, and conducts monitoring and evaluation.
\end{abstract}

Keywords: Communication Strategy, Radio Citra, Listeners Interest.

\begin{abstract}
Abstrak
Radio merupakan media komunikasi yang muncul pada era telekomunikasi. Radio sebagai media komunikasi memberikan kemudahan bagi masyarakat untuk memperoleh informasi. Seiring dengan perkembangan teknologi informasi yang tinggi, radio memiliki tantangan yang beragam untuk mempertahankan eksistensinya. Penelitian ini bertujuan untuk mengetahui strategi komunikasi yang digunakan oleh Radio Citra dalam meningkatkan minat pendengar.

Dalam penelitian ini, menggunakan paradigma post-positivis, dan termasuk jenis penelitian kualitatif. Penelitian ini menggunakan tiga teknik pengumpulan data, yaitu observasi, wawancara, dan dokumentasi. Teknik analisis data dalam penelitian ini menggunakan tahapan reduksi data, penyajian data, dan penarikan kesimpulan.

Hasil penelitian ini adalah bahwa strategi radio Citra dalam meningktkan minat pendengar dengan mengemas program acara yang menarik, menggunakan media sosial facebook, instagram dan streaming untuk siaran, memfungsikan penyiar sebagai ujung tombak dan jantung, aktif terjun ke masyarakat secaa langsung, dan menggunakan strategi kesesuaian. Radio Citra juga membuat perencanaan program yang matang, membuat produksi program, melakukan eksekusi program untuk
\end{abstract}


Cyber Sex Sebagai Implikasi Perkembangan Teknologi Komunikasi

Galih Akbar Prabowo

menayangkan program sesuai dengan rencana yang sudah ditetapkan, serta melakukan pengawasan dan evaluasi.

\section{Kata Kunci : Strategi Komunikasi, Radio Citra, Minat Pendengar.}

\section{Pendahuluan}

Perkembangan dan kemajuan media massa dari tahun ke tahun semakin meningkat seiring dengan kemajuan teknologi komunikasi dan informasi. Masyarakat sekarang memiliki ketergantungan pada informasi yang cepat, aktual, dan terpercaya. Salah satu media yang menyajikan informasi dengan cepat dan ditunjang dengan media teknologi adalah radio atau lembaga penyiaran.

Keberadaan lembaga penyiaran di Indonesia semakin kuat setelah disahkannya Undang-undang Nomor 32 Tahun 2002 tentang penyiaran. Masing-masing lembaga penyiaran mempunyai fungsi sendiri-sendiri. Misalnya Lembaga Penyiaran Publik adalah lembaga penyiaran yang berbentuk badan hukum yang didirikan oleh negara, bersifat independent, netral dan tidak komersil, berfungsi memberikan layanan kepentingan untuk masyarakat. Berskala besar yang secara geografis meliputi wilayah Nasional. Lembaga Penyiaran Swasta adalah lembaga penyiaran yang bersifat komersial berbentuk badan hukum Indonesia, yang dibidang usahanya menyelenggrakan jasa penyiaran radio atau televisi. Lembaga Penyiaran Komunitas merupakan lembaga penyiaran yang berbentuk badan hukum indonesia didirikan oleh komunitas tertentu, bersifat independent dan tidak komersial, dengan daya pancar rendah, luas jangkauan wilayah terbatas, serta untuk melayani kepentingan komunitasnya. Lembaga Penyiaran Berlangganan merupakan lembaga penyiaran berbentuk badan hukum Indonesia, yang bidang usahanya hanya menyelenggarakan jasa penyiaran berlangganan dan wajib terlebih dahulu memperoleh izin penyelenggaraan penyiaran berlangganan.

Radio merupakan salah satu media penyiaran komunikasi tertua dan paling bersejarah. Pada tahun 1887 J.C Maxwell dan Helmholtz Hertz pertama kali berhasil membuat gelombang radio. Kemudian penemuan itu terus berkembang dan menjadi media massa yang sampai sekarang masih dipercaya masyarakat (Morissan,2008:2).

Radio sebagai media massa, memiliki peran untuk menyampaikan berbagai informasi, seperti peristiwa di lingkungan sekitar, pemerintahan, ekonomi, politik, sosial, dan lain sebagainya. Selain peran menginformasikan, radio juga berperan dalam mengedukasi masyarakat. Melalui radio, masyarakat menjadi mengerti dan paham tentang 
suatu informasi (Thirsyad, 2004:3). Radio juga memiliki fungsi sebagai media hiburan. Misalnya melalui lagu-lagu yang diputar, penyiar yang seru dan asyik, dan lain sebagainya.

Komunikasi melalui media radio merupakan komunikasi yang menggunakan media audio. Perbedaan media audio dengan media visual terletak pada bentuknya. Media audio hanya bisa didengar oleh indra pendengaran (telinga), sedangkan visual dapat dilihat oleh indra penglihatan (mata). Jika media audio visual yaitu yang bisa didengar dan dilihat secara bersamaan (Ahmad,2015:243). Radio mempunyai beberapa keunggulan dari media lain, misalnya jangkauannya dapat dinikmati masyarakat luas dengan harga yang relatif murah. Dengan semakin canggihnya radio, maka informasi yang disajikan berfariatif dan efektif. Salah satu radio yang eksis hingga saat ini di Kabupaten Kendal, dan menjadi satusatunya radio di Kaliwungu adalah radio citra.

Radio Citra adalah salah satu radio yang menggunakan siaran penyiaran lokal sebagai lembaga publik yang independen dan netral. Radio Citra memiliki berbagai program acara yang menarik minat pedengar. Salah satunya terdapat program-program acara lagu dangdut masa kini dan nostalgia sekitar tahun 1990-an. Radio Citra adalah radio di Kota Kendal yang menyajikan program acara pengajian atau istighosah. Hal tersebut bertepatan dengan lokasi Radio Citra yang berada di Kaliwungu, yang mendapat predikat kota santri. Pengajian istighosah bersama dan pemutaran lagu-lagu bertema rohani menjadi karakteristik di Radio Citra. Motto yang digunakan di Radio Citra adalah memberikan hiburan sekaligus informasi-informasi keagamaan.

Radio Citra merupakan radio yang mengakomodir kebutuhan masyarakat dan tetap mempertahankan nilai-nilai sosial. Perbedaan dengan radio yang lain adalah seluruh siarannya berupa konten-konten yang menyesuaikan karakteristik dan minat pendengar masyarakat Jawa Tengah.

\section{Metode Penelitian}

Dalam penelitian ini, peneliti menggunakan paradigma post-positivis. Penelitian ini termasuk jenis penelitian kualitatif. Penelitian kualitatif mengacu pada makna, definisi konsep, karakteristik, simbol, dan deskripsi hal-hal dan bukan pada jumlah atau ukurannya. Penelitian ini menjawab mengapa dan bagaimana fenomena tertentu dapat terjadi. Fokus penelitian kualitatif adalah kompleks dan luas. Peneliti kualitatif bermaksud untuk memberi makna atas fenomena secara holistik dan memerankan dirinya secara aktif dalam keseluruhan proses studi. Oleh karena itu, temuan-temuan dalam studi kualitatif sangat dipengaruhi oleh nilai dan persepsi peneliti (researcher's values and perception) (Danim, 2015:35). 
Alasan peneliti menggunakan pendekatan kualitatif adalah karena dalam penelitian ini data yang dihasilkan berupa data deskriptif yang diperoleh dari data-data berupa tulisan, kata-kata dan dokumen yang berasal dari sumber atau informan yang diteliti dan dapat dipercaya. Kajian penelitian ini tentang strategi komunikasi radio Citra FM Kendal dalam meningkatkan minat pendengar.

Dalam penelitian ini terdapat beberapa tipe informan pada tahap pengambilan sumber data. Informan kunci dalam penelitian ini adalah Rudiyanto S.E (Staff manajer Radio Citra FM) dan Vivi Rosmalia A.Md ( ketua penyiar). Sedangkan untuk informan tambahan yang akan membantu untuk menambah informasi peneliti adalah Ganjar Hermawan, Nana Ria Indah Safitri, dan Mama Sinta yang merupakan pendengar radio Citra FM Kendal.

Dalam penelitian ini menggunakan tiga teknik pengumpulan data, yaitu observasi, wawancara, dan dokumentasi. Peneliti menggunakan metode observasi untuk mengamati dan mencatat secara sistematis tentang strategi komunikasi Radio Citra FM dalam meningkatkan minat pendengar. Peneliti melakukan pengamatan langsung untuk mengetahui perencanaan program serta bagaimana penjadwalan program acara yang berlangsung. Teknik analisis data dalam penelitian ini menggunakan tahapan reduksi data, penyajian data, dan penarikan kesimpulan.

\section{Kajian Teori}

\section{Strategi Komunikasi}

Strategi komunikasi pada hakikatnya adalah perencanaan (planning) dan manajemen (management) untuk mencapai suatu tujuan. Strategi komunikasi merupakan paduan dari perencanaan komunikasi dan manajemen komunikasi untuk mencapai suatu tujuan (Effendy, 2003:301). Tujuan utama strategi komunikasi menurut R. Wayne Pace, Brent D. Peterson dan M. Dallas Burnett dalam (Efendy, 2009:32) dalam Techniques for Effective Communication adalah sebagai berikut :

1. To secure understanding, yaitu untuk memastikan bahwa terjadi suatu pengertian dalam berkomunikasi. Andaikan ia sudah mengerti dan menerima, maka penerimaannya itu harus dibina.

2. To establish acceptance, yaitu bagaimana cara penerimaan itu terus dibina dengan baik.

3. To motive action, yaitu penggiatan untuk memotivasinya.

4. The goals which the communicator sought to archive, yaitu bagaimana mencapai tujuan yang hendak dicapai oleh pihak komunikator dari proses komunikasi tersebut.

Adapun fungsi dari strategi komunikasi sendiri adalah untuk menyebarkan pesan komunikasi yang bersifat informatif, persuasif, dan instruktif secara sistematis kepada 
sasaran untuk memperoleh hasil yang optimal. Menjembatani “cultural gap”, misalnya suatu program yang berasal dari suatu produk kebudayaan lain yang dianggap baik untuk diterapkan dan dijadikan milik kebudayaan sendiri sangat tergantung bagaimana strategi mengemas informasi itu dalam dikomunikasikannya. Faktor-faktor pendukung dalam menyusun strategi komunikasi yaitu pertama, mengenal khalayak. Khalayak itu aktif sehingga antara komunikator dengan komunikan bukan saja tejadi saling hubungan, tetapi juga saling mempengaruhi. Kedua, menyusun pesan, yaitu menentukan tema dan materi. Syarat utama dalam mempengaruhi kalayak dari pesan tersebut ialah mampu membangkitkan perhatian. Awal efektivitas dalam komunikasi ialah bangkitnya perhatian dari khalayak terhadap pesan-pesan yang disampaikan dan Menentukan metode dalam dua aspek.

Strategi Komunikasi yang dilakukan agar menarik perhatian atau minat pendengar radio menurut Eastman dalam teori prorgramming meliputi: a) Strategi Kesesuian (compability) strategi ini meliputi kesesuaian penjadwalan, pemilihan tipe program, dan pokok masalah terhadap kebutuhan khalayak pendengar. Radio siaran harus membuat program yang sesuai dengan kegiatan sehari-hari pendengarnya dan selalu berbeda-beda dari waktu ke waktu. Karena itu untuk menyesuaikan kondisi dan kebiasaan pendengar, perlu dilakukan pemilihan di penjadwalan yang tepat. b) Strategi Pembentukan Kebiasaan ( Habbit Formation) pembentukan kebiasaan disini adalah membentuk kebiasaan-kebiasaan mendengarkan yang dihasilkan dari adanya penjadwalan program acara melalui produksi yang seksama, oleh karena itu, penyajian setiap program acara dilakukan secara rutin dan selalu menempatkan waktu yang sama pada jangka waktu tertentu.

Semakin lama waktu pendengar mengikuti program, maka akan semakin berdampak pada pemasangan iklan. Sehingga iklan yang ada di radio citra memiliki keunikan, menyenangkan dan menggunakan penyampaian dengan basa tutur pendengarnya. c) Strategi Pengontrolan Arus Pendengar (Control of Audience flow) pengontrolan arus pendengar dilakukan dalam rangka memaksimalkan pendengar yang mengalir dari satu program ke program berikutnya. Dan untuk meminimalkan pendengar mengalihkan saluran ke pihak pesaing.

Hal ini dapat dilihat dari menyajikan program yang berbeda dengan radio lain (Countering) atau menyajikan program acara serupa atau mirip dengan radio siaran lainnya (Blunting). d) Strategi Penyimpanan Sumber-sumber program ( Conservation of Program Resource) penyimpanan sumber-sumber program ini dimaksudkan agar program bisa di 
pakai suatu saat. Tapi tentu saja dengan cara menyajikan yang berbeda. Ketersediaan materi dan sumber daya lain sebagai pendukung program harus benar-benar di perhitungkan karena jam siaran yang terus menerus sepanjang hari, diantaranya dengan mengemas ulang materi tersebut dengan pendekatan dan cara penyajian yang berbeda. e) Strategi Daya Penarik Massa (Mass Appeal) Daya penarik massa sangat penting untuk diperhatikan karena stasiun-stasiun penyiaran mendapatkan keuntungan dengan cara semaksimal mungkin untuk menarik perhatian pendengar dengan mengemas program siaran semenarik mungkin dan sesuai dengan kebutuhan pendengar.

Strategi komunikasi dapat dilakukan dengan menggunakan media sosial, salah satunya media sosial facebook, instagram maupun media streaming. Pengguna facebook bisa dengan mudah berkomunikasi tanpa mengenal jarak jauh maupun dekat. Media sosial merupakan media yang sedang populer untuk pengembangan bisnis di masa kini.

\section{Komunikasi Massa dan Radio}

Komunikasi massa adalah pesan-pesan yang dikomunikasikan melalui media massa pada sejumlah besar orang (Bitner-1980). Batasan komunikasi massa ini lebih menitik beratkan pada komponen-komponen dari komunikasi massa yang mencakup pesan-pesan, dan media massa (seperti koran, majalah, radio, tv dan film) serta khalayak. Wilbur Schramm dalam bukunya (Komala , dkk) mengatakan bahwa untuk berlangsungnya suatu kegiatan komunikasi, minimal diperlukan tiga komponen yaitu source, massage, destination, atau komunikator, pesan, komunikan.

Apabila salah satu dari ketiga komponen tersebut tidak ada, maka komunikasi tidak dapat berlangsung. Komunikasi massa menurut Tan dan Wright dalam Liliweri (1991) merupakan bentuk komunikasi yang menggunakan saluran (media) alam menghubungkan komunikator dan komunikan secara massal, berjumlah banyak, bertempat tinggal yang jauh berpencar, sangat heterogen dan menimbulkan efek tertentu. Menurut Wright (1956) komunikasi massa didefinisikan dalam tiga ciri :

1. Komunikasi massa diarahkan kepada audiens yang relatif besar, heterogen dan anonim.

2. Pesan-pesan yang disebarkan secara umum, sering dijadwalkan untuk mencapai sebanyak mungkin audiens secara serempak dan sifatnya sementara.

3. Komunikator cenderung berada atau beroperasi dalam sebuah organisasi yang kompleks dengan biaya yang besar. 
Komunikasi massa memiliki berbagai fungsi, seperti Penafsiran (interpretation), yaitu berbentuk komentar dan opini yang ditunjukkan kepada khalayak, serta di lengkapi perspektif berita. Fungsi pertalian, yaitu dapat menyatukan anggota masyarakat yang beragam berdasarkan kepentingan dan minat yang sama tentang sesuatu. Fungsi penyebaran nilai-nilai (transmission of Values), yaitu dengan cara media massa itu didengar, dan memperlihatkan kepada kita bagaimana mereka bertindak dan apa saja yang diharapkan oleh mereka. Fungsi hiburan (entertaintment), yaitu Televisi dan Radio sudah jelas ada fungsi hiburan. Sedangkan surat kabar, majalah dalam bentuk rubrik-rubrik hiburan selalu ada, misalnya cerita pendek, cerita panjang atau cerita bergambar (Ardianto, 2004:87)

Karakteristik Komunikasi Massa menurut William R. Rivers dkk (2009): komunikasi yang bersifat satu arah, selalu ada proses seleksi khalayak dan menjangkau khalayak, membidik sasaran tertentu atau segmentasi yang dilakukan oleh institusi sosial (lembaga media/pers), media dan masyarakat saling memberi pengaruh/interaksi. McQuail menyebut ciri utama komunikasi massa dari segi sumber. Dalam artian bukan satu orang, tapi organisasi formal, "sender"-nya seringkali merupakan komunikator profesional. Pesan : beragam, dapat diperkirakan, dan diproses, distandarisasi, dan selalu diperbanyak, sebagai produk dan komoditi yang bernilai tukar. Hubungan pengirim-penerima bersifat satu arah, impersonal, bahkan mungkin selalu sering bersifat non-moral dan kalkulatif. Penerima merupakan bagian dari khalayak luas yang mencakup kontak secara serentak antara satu pengirim dengan banyak penerima.

Media massa adalah bentuk media yang dirancang untuk menjangkau khalayak ramai, diantaranya televisi, film radio, koran, majalah, buku, catatan, video game dan internet. Banyak peneliti telah dilakukan pada abad masa lalu untuk mengukur efek media massa pada populasi, untuk menemukan teknik terbaik dalam mempengaruhinya. Menurut Kamus Besar Bahasa Indonesia ( 2005:756) “ media massa merupakan sarana dan saluran resmi sebagai alat komunikasi untuk menyebarkan berita dan pesan kepada masyarakat luas.

Radio merupakan teknologi yang menggunakan cara modulasi dan radiasi gelombang elektromagnetik yang melintas dan juga merambat melalui udara. Dapat merambat lewat ruang angkasa yang hampa udara, karena gelombang ini tidak memerlukan sebuah medium pengangkut, seperti molekul udara. berbeda dengan media cetak, pembaca bisa mengulang bacaan yang sudah dibaca bahkan untuk beberapa kali. 
Tetapi radio adalah sarana hiburan termurah dan tercepat sehingga menjadi media utama untuk mendengarkan musik. (Indah R, dkk;2014). Karakteristik Radio sebagai berikut:

1. Auditori : karena untuk didengar, isi siaran bersifat selintas lalu dan tidak bisa diulang

2. Transmisi : proses penyampaian informasi melalui pemancar (transmisi)

3. Mengandung gangguan : gangguan timbul-tenggelam (fading) dan gangguan teknis seperti channel noise factor

4. Theater of mind : sifatnya yang auditif, radio mencipta gambar dalam imajinasi pendengar dengan kekuatan kata dan suara

\section{Konvergensi Media}

Konvergensi Media merupakan salah satu perkembangan media massa yang melibatkan banyak fakta teknologi di dalamnya. Kehadiran internet mendorong media massa menerapkan konsep konvergensi media seperti media online, e-paper , e-books, radio streaming, media sosial, yang digabungkan dengan media lainnya. Konvergensi pada umumnya berarti persimpangan anatara media lama dan baru (jenkins,2008:2). Konvergensi media tidak hanya pergeseran teknologi atau proses teknologi, namun juga termasuk pergeseran dalam paradigma industri, budaya, dan sosial yang mendorong konsumen untuk mencari informasi baru.

Konvergensi media terjadi dengan melihat bagaimana individu berinteraksi dengan orang lain pada tingkat sosial dan menggunakan berbagai platform media untuk menciptakan pengalaman baru. Bentuk-bentuk baru media dan konten yang menggabungkan kita secara sosial, dan tidak hanya kepada konsumen lain, tapi untuk para produsen perusahaan media. Teori konvergensi yang diteliti oleh henry Jenkins dalam bukunya yang berjudul " convergensi culture" pada tahun 2008, menyatakan bahwa konvergensi media merupakan proses yang terjadi sesuai dengan perkembangan budya masyarakat. Konvergensi media ini menyatukan 3C yaitu computing (memasukkan data melalui komputer), Communication ( komunikasi), dan Content (materi / isi konten). Media konvergensi berimplikasi bahwa media massa bisa dijadikan sebagai pusat keuntungan bisnis, dimana terdapat empat bagian bentuk, diantaranya chains, broadcast, networks, conglomertae dan vertical integration ( Biagi, 2012:12)

Media massa mengalami beberapa tahap perubahan, informasi, dan bahkan bermetaforfosis. Roger Fidler (2003) menyebut fase berbagai perkembangan media dengan nama mediamorfosis. Dalam pandangan Fidler, mediamorfosis memiliki tiga konsep, yaitu koevolusi, konvergensi, dan kompleksitas. Ia mendefinisikan mediamorfosis sebagai 
informasi media komunikasi yang biasanya ditimbulkan akibat hubungan timbal balik yang rumit antara berbagai kebutuhan yang dirasakan, tekanan persaingan politik serta berbagai inovasi sosial dan teknologi (2003:34-42).

Kehadiran internet mengubah secara drastis dan dramatis perkembangan media massa. Setidaknya internet memicu dua perubahan mendasar dalam lingkungan media massa. Pertama, perubahan proses jurnalistik, termasuk digitalisasi. Kedua, perubahan bentuk dan format organisasi media. Jika sebelumnya setiap jenis media massa berdiri sendiri atau memiliki organisasi dan manajemen mandiri, kini mereka bergabung dalam satu kesatuan yang dikenal dengan konvergensi. Maka tidak heran bila sekarang hampir semua media cetak dan elektronik menyertainya dengan bentuk berita online, e-paper, dan live streaming.

Perubahan mendasar pada jurnalisme media lantas memunculkan terminologi mengenaskan bernama krisis jurnalisme meski kata "krisis" dipandang berlebihan. Krisis jurnalisme didiagnosis meliputi serangkaian masalah, yaitu yang berkaitan dengan waktu, uang, otonomi, dan perubahan budaya. Sementara itu, perubahan pada bentuk dalam organisasi media menghadirkan konvergensi media. Perubahan bentuk ini sebagai salah satu alternatif untuk bertahan atau tetap survive dari perubahan zaman akibat kemajuan teknologi komunikasi dan informasi. Meskipun demikian, konvergensi media adalah konsep yang ambigius. Istilah ini dipergunakan secara berbeda. di satu sisi, ia sebagai tempat bertemu (jaringan berkumpul termasuk untuk wilayah sosial).

Henry jenkins mendefinisikan konvergensi sebagai proses penyatuan yang terus menerus yang terjadi diantara berbagai bagian media seperti teknologi, industri, konten dan khalayak. Dan itu terjadi secara terus menerus. Sedangkan Burnett and Marshall (2003:01) mendefinisikan konvergensi sebagai penggabungan industri media, telekomunikasi, dan komputer menjadi sebuah bentuk yang bersatu dan berfungsi sebagai media komunikasi dalam bentuk digital. Konvergensi media adalah bentuk media pertukaran diantara media di berbagai karakteristik dan platformnya. Komputer menawarkan sebuah bentuk ke radio dan televisi. Telepon seluler yang memiliki gambar dan teks dapat mengambil beberapa karakteristik komuputer dan radio.

Konvergensi media ternyata bukan hanya berpengaruh pada perubahan proses jurnalistik, tetapi juga menyangkut ke berbagai aspek kehidupan. Ia akan berdampak pada konsumsi media masyarakat, persepsi publik, penyebaran informasi, dan literasi media, 
misalnya : singkat kata konvergensi media bakal menghadirkan kontruksi sosial media baru yang belum pernah terjadi sebelumnya. (Rahma Sugiharti, 2014:89).

\section{Hasil dan Pembahasan}

Perkembangan masyarakat yang semakin modern menuntut berbagai pemenuhan kebutuhan, termasuk kebutuhan akan hiburan dan informasi. Kehadiran radio sebagai media informasi, pendidikan, dan hiburan yang sehat menjadi salah satu kebutuhan masyarakat Kendal. Melihat realitas akan kebutuhan masyarakat terhadap berdirinya sebuah lembaga penyiaran, maka berdasarkan pertimbangan dan diskusi panjang dengan berbagai pakar akademisi, tokoh Agama Islam, dan masyarakat di Kabupaten Kendal, owner radio Citra mendirikan sebuah lembaga penyiaran radio sebagai Pusat Informasi dan Hiburan untuk memenuhi kebutuhan masyarakat. Tepatnya, Pada tahun 1991, PT. Radio Citra Duta Buana yang memiliki nama udara Citra FM berdiri secara resmi.

Selama mengudara, radio Citra telah menjadi bagian dari sejarah dunia broadcast di Kabupaten Kendal. Selama ini radio citra mencoba untuk melakukan yang terbaik demi terbentuknya karakter dan jati diri anak bangsa melalui informasi, dan hiburan yang sehat serta mendidik. Radio Citra memilih segmen menengah ke bawah sebagai konsekwensi logis melihat masyarakat Kendal berada di daerah pedesaan. Alasan tersebut dipilih bukan semata untuk meninggalkan segmen menengah ke atas, tetapi segmen tersebut tetap menjadi perhatian radio citra untuk menjadi target, meskipun porsinya tidak terlalu besar.

Radio Citra memiliki maksud dan tujuan didirikan, misalnya sebagai pusat Informasi dan hiburan yang mampu mengembangkan potensinya menuju terciptanya tatanan kehidupan masyarakat yang adil, makmur, dan sejahtera, menjadi media bisnis yang profesional, sebagai perekat serta kontrol sosial yang terpercaya, dan menjadi media pemasang iklan, serta sebagai media radio yang mengedepankan kepentingan lokal dalam rangka menopang optimalisasi pembangunan daerah seutuhnya.

Radio Citra memiliki berbagai strategi untuk meningkatkan minat pendengar, misalnya strategi program acara. Dalam strategi ini ada tiga unggulan program acara yang menarik dan berbeda dari radio-radio yang lain. Misalnya program dangdut ceria yang memberikan lagu-lagu terbaru dan terkini tentang dunia dangdut. Hal tersebut dilakukan karena mayoritas masyarakat Kendal menyukai lagu-lagu bergenre dangdut. Lagu-lagu terbaru dan klasik dikemas mengikuti rundown acara sesuai dengan kebutuhan dari pendengar.

Strategi program acara yang lain adalah "Bintang Kecil". Dalam program ini, radio Citra mengundang anak-anak sekolah di tingkat Paud maupun TK untuk menjadi bintang 
tamu dalam program acara. Manfaat dan tujuan dari acara ini selain untuk menambah wawasan, adalah untuk memberikan manfaat kepada psycology anak, tentang belajar diluar, dan mengenal dunia luar. Dengan acara ini diharapkan anak-anak dapat bergembira, senang tetapi tetap belajar dengan mengenal lagu-lagu anak di Radio Citra. Program acara bintang kecil diharapkan menjadi nuansa baru bagi pendidikan, bahwa di era konvergensi media. radio masih tetap bisa menjadi media yang kreatif dan inovatif berperan di masyarakat Kota Kendal.

Selain itu, program acara lain yang menjadi unggulan radio citra adalah pengajian dan istighosah. Pogram pengajian dan istighosah membuat Radio Citra berbeda dengan Radio lain yang berada di Kota Kendal. Acara ini dilakukan oleh semua crew yang ada di Radio Citra. Program pengajian diputar dua kali, yaitu pukul 06.00 - 07.00 WIB dan sebelum adzan dhuhur, yaitu pukul 10.00 - 11.45 WIB.

Untuk meningkatkan minat pendengar, Radio Citra juga menayangkan acara siaran di sosial media online facebook. Seiring dengan majunya teknologi Radio Citra menggunakan media sosial online Facebook. Strategi ini dikonsep dengan melakukan perencanaan membuat story di halaman beranda dan dibagikan kepada publik, sehingga pesan yang masuk melalui massenger, komentar maupun via telephone di facebook dapat diterima dan disesuaikan oleh penyiar dengan pendengar. Hal tersebut juga berkaitan dengan teori programming yaitu kesesuaian, dimana penyiar menyesuaikan kebutuhan dari seorang pendengar dengan memenuhi permintaan.

Selain facebook, Radio Citra juga eksis di media sosial Instagram. Dengan adanya media sosial Instagram, Radio Citra berupaya terus mengasah strategi sesuai kemajuan teknologi dan mengikuti trend baru. Hal tersebut juga sebagai bagian dari implementasi tagline dari Radio Citra, yaitu informasi dan hiburan.

Radio Citra memiliki strategi untuk meningkatkan pendengar melalui penyiar. Dalam media radio, penyiar merupakan jantung dari radio. Penyiar radio Citra dalam tugas kerjanya diintruksikan untuk memiliki sifat humble dan cerdas. Humble diartikan ramah kepada pendengar tetapi tetap dalam batasan antara penyiar dengan seorang pendengar. Kedua, penyiar harus memiliki sifat smart, yaitu pintar. Pintar mengatur waktu, dan menguasai alat-alat program, hal ini bertujuan agar saat siaran penyiar dapat menjalankan dengan lancar, dan acara dapat dinikmati pendengar dengan nikmat.

Radio memiliki sifat auditori (hanya menghantarkan suara). Mengemas program acara yang menarik dan lebih hidup merupakan tugas dari seorang penyiar. Strategi 
melalui penyiar dilakukan oleh radio Citra karena menyesuaikan karakteristik pendengar yang heterogen. Pendengar memiliki karakteristik yang berbeda, pendengar memiliki kondisi fisik, keadaaan dan psikis yang berbeda-beda. Penyiar radio Citra diwajibkan smart dan humble dalam melakukan siaran program acara.

Karakteristik Penyiar radio citra untuk meningkatkan minat pendengar adalah memiliki kesesuaian gaya siaran dengan acara yang dibawakan, misalnya saat acara formal penyiar menggunakan bahasa formal, sapaan pendengar "anda", bahasa yang digunakan saat siaran adalah bahasa Indonesia. Untuk acara tertentu, bahasa di kombinasi dengan bahasa asli kendal, misalnya dalam bahasa jawa orang asli kendal berciri khas dengan ucapan (meni, nani, raa, huum,iyo lan yen). Tetapi jika acara non-formal, bahasa yang dibawakan oleh penyiar Radio Citra dibawakan dengan santai, humoris, disertai dengan bahasa Jawa, karena mayoritas di kendal menggunakan bahasa Jawa, sehingga pendengar merasa penyiar seperti teman, dan tidak canggung untuk bergabung atau join di Radio Citra.

Penyiar radio Citra berupaya untuk selalu memenuhi permintaan pendengarnya pada waktu on di udara, saat proses tanya jawab ataupun request lagu dan kirim salam, sehingga pendengar merasa puas. Penyiar radio Citra juga memberikan informasi atau tips saat siaran berlangsung. Hal tersebut bertujuan untuk mendapatkan informasi dan tips, pendengar dapat mendengarkan musik dan mendapatkan informasi. Karakteristik memenuhi kebutuhan pendengar merupakan salah satu hal menarik dalam Radio Citra. Radio Citra juga mempunyai strategi komunikasi brand yang selain lewat media off air, online, dan off line. Radio Citra aktif terjun ke masyarkat langsung dengan memberikan selembaran sticker yang berkaitan dengan strategi komunikasi radio untuk meningkatkan minat pendengar.

Radio merupakan media komunikasi yang muncul pada era telekomunikasi. Kemunculan radio sebagai media komunikasi memberikan kemudahan bagi masyarakat untuk memperoleh informasi waktu itu. Radio menjadi salah satu media yang menyebarkan informasi melalui audio atau suara, namun di era yang sekarang ini minat masyarakat untuk mendengarkan radio menjadi lebih sedikit, mungkin alasannya adalah karena radio hanya memberikan informasi berupa audio saja.

Dalam dinamikanya, radio Citra berupaya untuk menyesuaikan diri dengan perkembangan zaman. Strategi pertama yang dilakukan oleh radio Citra untuk menjaga dan meningkatkan minat pendengar adalah membuat perencanaan yang baik. Dalam industri penyiaran, perencanaan merupakan unsur terpenting karena siaran memiliki pengaruh, 
dampak yang kuat dan besar. Perencanaan meliputi : perencanaan produksi, pengadaan materi siaran yang di susun menjadi rangkaian mata acara harian, mingguan, dan prasarana, serta perencanaan administrasi (Trianto dalam Romli 2016).

Perencanaan adalah kunci dari sebuah program siaran. Morissan dalam Romli 2016, mengatakan ada 4 hal penting dalam merencanakan program siaran yaitu Product artinya materi program yang disukai pendengar, price artinya biaya yang dikeluarkan untuk memproduksi atau membeli program, place artinya kapan waktu siaran yang tepat, promotion artinya bagaimana memperkenalkan dan menjual acara sehingga mendapat iklan dan sponsor keempat hal tersebutlah yang menjadi kunci dalam sebuah perencanaan.

Perencanaan program acara dilakukan dengan berabagai medis, salah satunya media sosial. Salah satu bentuk perencanaan dengan menggunakan media sosial adalah dengan membuat story di whatsaap ketika program siaran. Pembuatan story dari program acara disesuaikan dengan jadwal program acara yang ada di Radio Citra.

Setelah perencanaan, yang diperhatikan oleh radio Citra adalah produksi program. Produksi program siaran merupakan ketrampilan memadukan wawasan, kreatifitas, dan kemampuan mengoperasikan peralatan produksi. Program dapat diperoleh dengan cara membeli atau meproduksinya sendiri (in-house Production). Kemampuan mengoperasikan peralatan produksi dalam hal ini wawasan dan kreatifitas. Wawasan dan kreatifitas dimiliki oleh seorang penyiar Radio Citra. Memproduksi suatu program siaran juga membutuhkan unsur-unsur daya tarik. Radio memiliki tiga unsur daya tarik yang melekat padanya, yakni: kata-kata lisan (spiken word), musik (music), efek suara (sound effect). Tiga hal diatas merupakan ciri khas dan daya tarik dari pada radio Citra sehingga kualitas produksi siarannya diminati dan menarik minat pendengar.

Ketersediaan alat-alat produksi juga menajadi masalah penting bagi para pendengar, seperti kurang baiknya kondisi pemancar yang dimiliki, serta alat-alat radio yang kondisinya sudah tidak baik. Di Radio Citra, alat-alat yang digunakan pada saat siaran menunjang dan memiliki fungsi sesuai dengan kegunaannya, sehinggga pada saat siaran berlangsung, hambatan-hambtan tidak muncul karena adanya gangguan teknis. Hal ini menjadi peran penting yang harus dilakukan oleh manajemen radio. Pemilihan penyiar yang memiliki wawasan dan cerdas dalam melakukan program siaran harus dipilih oleh seorang staaf radio, agar selama produksi siaran berlangsung dan dapat berjalan dengan lancar. 
Tahap berikutnya adalah Eksekusi Program. Eksekusi mencakup kegiatan menayangkan program sesuai dengan rencana yang sudah ditetapkan. Strategi penayangan program sangat ditentukan oleh bagaimana menata atau menyusun berbagai program yang akan ditayangkan. Menentukan jadwal penayangan suatu acara ditentukan atas dasar perilaku audience. Yaitu rotasi kegiatan mereka dalam satu hari dan juga kebiasaan mereka menonton televisi atau mendengarkan radio pada jam tertentu. Pada prinsipnya siaran radio harus dapat menemani aktivitas apapun. Pada saat penyusunan jadwal, seluruh penyiar di Radio Citra melakukan rapat koordinasi dengan kepala staff Radio Citra. Strategi dari penayangan siaran di Radio Citra dibuat sesuai dengan Rundown acara dan disesuaikan dengan jam-jam istirahat kerja atau mobilitas dari pendengar. hal ini seperti yang dikatakan Romli dalam bukunya penempatan waktu sebuah program akan efektif bila dilakukan dengan memperhatikan mobilitas pendengar karena akan lebih tepat sasaran.

Radio Citra memiliki strategi penjadwalan yang sudah di tata sesuai dengan perencanaan dan strategi untuk menarik minat pendengar di Kota Kendal. Dengan adanya perencanaan penyusunan jadwal hal ini dapat membuat para pendengar tidak mengganti ke stasiun lain, dan setia kepada radio citra. Hambatan yang sering dialami dalam hal ini yaitu sifat kebiasaan dan keterlibatan antara penyiar dengan radio. Biasanya radio lain memiliki karakteristik yang dalam penyampaian sapa opening atau salam-salam membatasi percakapan. Di Radio Citra, peran penyiar sangat terlibat dan mereka seperti nyata dalam keadaan sehari-hari. Hal ini berkaitan dengan sifat radio yang memiliki sifat auditori. Karakteristik dari penyiar yang memiliki kebiasaan dalam menyapa dan kesesuaian dalam menanggapi pendnegar merupakan salah satu strategi perogamming yang dilakukan oleh Radio Citra agar tetap eksis di hati pendengar.

Tahap berikutnya adalah pengawasan dan evaluasi. Pengawasan dan evaluasi menentukan seberapa jauh suatu rencana dan tujuan sudah dapat diwujudkan oleh stasiun penyiaran. Dalam proses ini Radio Citra melakukan pengawasan dengan baik dan sesuai prosedur. Pengawasan terdiri dari internal dan ekstrenal. Keduanya berjalan dengan baik bahkan mereka melibatkan juga pendengar dalam proses evaluasi.

Tahap pengawasan dan evaluasi dari radio citra melibatkan peran dari pendengar. hal ini dilakukan Radio Citra karena sebuah acara radio akan memiliki sebuah rating jika radio tersebut memilah dan memilih acara-acara yang bagus dan menarik. Fungsi pengembangan dari konvergensi media dengan membuat konten yang kreatif, menyajikan lagu-lagu terbaik dan seorang penyiar memiliki kreatifitas yang bagus, maka akan membuat 
radio maju dan berkembang. Seorang pendengar tentunya setiap hari ingin mendengarkan sesuatu yang berbeda, dengan adanya penyajian program yang berbeda setiap harinya.

\section{Kesimpulan}

Berdasarkan hasil dan pembahasan, peneliti mengambil kesimpulan bahwa strategi komunikasi yang dilakukan Radio citra di kendal adalah dengan mengemas program acara yang menarik dan berbeda, seperti dangdut ceria, bintang kecil, dan istighosah atau pengajian. Kedua, Radio Citra menggunakan media sosial facebook, instagram dan streaming untuk siaran. Ketiga, radio Citra menggunakan penyiar sebagai ujung tombak dan jantung. Penyiar diintruksikan memiliki sifat humble dan cerdas. Humble diartikan ramah kepada pendengar tetapi tetap dalam batasan antara penyiar dengan seorang pendengar. Penyiar juga diminta cerdas dan Pintar mengatur waktu dan menguasai alat-alat program.

Keempat, Radio Citra aktif terjun ke masyarakat langsung dengan memberikan selembaran sticker yang berkaitan dengan strategi komunikasi radio untuk meningkatkan minat pendengar. Kelima, radio citra menggunakan strategi kesesuaian, artinya mengutamakan kesesuaian penjadwalan, pemilihan tipe program, dan pokok masalah terhadap kebutuhan khalayak pendengar, membuat program yang sesuai dengan kegiatan sehari-hari pendengarnya dan selalu berbeda-beda dari waktu ke waktu.

Dalam melaksanakan strategi komunikasi, radio Citra membuat perencanaan program yang matang, membuat produksi program yang merupakan ketrampilan memadukan wawasan, kreatifitas, dan kemampuan mengoperasikan peralatan produksi, melakukan eksekusi program untuk menayangkan program sesuai dengan rencana yang sudah ditetapkan, serta melakukan pengawasan dan evaluasi guna menentukan seberapa jauh suatu rencana dan tujuan dapat diwujudkan oleh stasiun penyiaran. 


\section{Referensi}

Abrar, Ana Nadya. 2003. Teknologi Komunikasi : Perspektif Ilmu Komunikasi. Yogyakarta : LESFI.

Biagi, Shirley. 2010. Media/Impact : Pengantar Media Massa, Edisi 9. Jakarta : Salemba Humanika.

Fiske, John. 2007. Cultural and Communication Studies : Sebuah Pengantar Paling Komprehensif. Yogyakarta : Jalasutra

Flew, Terry. 2005. New Media : An Introduction, 2nd Edition. Australia : Oxford University Press.

Green, Lelia. 2002. Communication, Technology, and Society. Australia : Allen \& Unwin.

Hartley, John. 2010. Communication, Cultural, and Media Studies : Konsep Kunci. Yogyakarta : Jalasutra.

Nasution, Zulkarnain. 2010. Teknologi Industri Media dan Perubahan Sosial. Malang : Program Studi Magister Sosiologi UMM.

Noegroho, Agoeng. 2010. Teknologi Komunikasi. Yogyakarta : Graha Ilmu.

Pavlik, John Vernon. 1996. New Media Technology : Cultural and Commercial Perspectives. Massachusets : Needham Height.

Rogers, Everett M. 1986. Communication Technology: The New Media in Society. New York : The Free Press.

Thurlow, Crispin, et. al. 2004. Computer Mediated Communication : Social Interacion and The Internet. London : Sage Publication Ltd.

Wahid, Abdul \& Mohammad Labib. 2005. Kejahatan Mayantara (Cybercrime). Bandung: Refika Aditama.

West, Richard \& Lynn H. Turner. 2010. Introducing Communication Theory : Analysis and Application, Fourth Edition. New York : Mc Graw Hill.

\section{$\underline{\text { Referensi Internet }}$}


Amarullah, Amir. 2010. Indonesia Pengakses Situs Porno Tertinggi.

(www.teknologi.vivanews.com/news/read/164817-indonesia-pengakses-situsporno-tertinggi Akses 8-3-2021).

Muntako, Kiki. 2011. Indonesia Belanja Situs Porno Rp 85,5 Trilyun per Bulan.

(http://sosbud.kompasiana.com/2011/04/13/indonesia-belanja-situs-porno-rp-855trilyun-per-bulan/ Akses 8-3-2021).

Artikel "Knowledge is Power, Ignorance is Weakness"(2009)

(www.bijisesawi.com/index.php?option=com_content\&view=article\&id=73:knowledg e-is-power-ignorance-is-weakness\&catid=38:the-way-of-cross Akses 9-3-2021).

Artikel "Gambaran Perilaku Seks Pada Remaja"

(www.padpdf.com/2a/2ae0d8bcbecbb1cd-download.pdf Akses 10-3-2021). 